\title{
The Siamese Twins: Citizenship Rights, Cleavage Formation, and Party-Union Relations in Western Europe*
}

\author{
BERNHARD EBBINGHAUS
}

Prophecies of doom for both working-class party and labor unions have gained popularity in the Western industrial democracies over the last two decades. ${ }^{1}$ The "old" Siamese twins, working-class party and labor unions, have a century-long history of their combined struggle to achieve political and industrial citizenship rights for the working class. ${ }^{2}$ Both forms of interest representation are seen as facing new challenges if not a crisis due to internal and external changes of both long-term and recent nature. ${ }^{3}$ However, despite these prophecies political parties and union movements have been differently affected and have responded in dissimilar ways across Western Europe. The Siamese twins, party and unions, as social institutions, their embeddedness in the social structure, and their linkages, were molded at an earlier time with long-term consequences. Hence, we cannot grasp today's political unionism, partyunion relations and organized labor's capacity for change, if we do not understand the social and political conditions under which the organization of labor interests became institutionalized. An understanding of the origins and causes of union diversity helps us to view the variations in union responses to current challenges.

* This paper is a slightly revised version of CSSC Working Paper, no. 203 (New York, 1994) under the same title, which includes also an appendix on "Events and Changes in Electoral and Corporate Channels, Western Europe, ca. 1830-1990", pp. i-xiii, that is not reproduced here. The reader is referred to the working paper appendix for a documentation of the events and names of organizations used in the text and tables. I am thankful to Charles Tilly, Lee R. Whelchel, and the editors of IRSH for succinct and compelling comments.

${ }^{1}$ I use throughout this paper the term party in singular and unions in plural to indicate that the latter is commonly a set of multiple actors, in particular national unions that usually cooperate within a peak association.

2 The image of the "Siamese twins" is borrowed from Viktor Adler (1852-1918), founder and leader of the Austrian Social-Democratic Workers Party (1889).

${ }^{3}$ On the crisis of socialism see the recent readers: Christiane Lemke and Gary Marks (eds), The Crisis of Socialism in Europe (Durham, NC, 1992); William E. Paterson and - Alastair H. Thomas (eds), The Future of Social Democracy: Problems and Prospects of Social Democratic Parties in Western Europe (Oxford, 1986); Frances Fox Piven (ed.), Labor Parties in Postindustrial Societies (New York, 1991). On party-union relations see Andrew J. Taylor, Trade Unions and Politics: A Comparative Introduction (London, 1989); and "Trade Unions and the Politics of Social Democratic Renewal", West European Politics, 16 (1993), pp. 133-155. 
A comparative historical perspective helps us to understand the contingent diversity of political unionism. However, students of labor history often either claim the "uniqueness" of each national labor movement, or generalize from ideal-typical cases based on the few large (or important) countries. Both comparative strategies ultimately stress the "exceptionalism" of each individual or model country, provoking the question of "how many exceptionalisms are there?". Surely within the international labor movement, as well as across borders, the large national labor movements influenced the development in smaller countries, while the reverse was rarely the case. Yet we need to have a more encompassing view that not only focuses at singular cases but can place them into a grid of variables that account for the major variations. This paper will give a short overview of the formation of political cleavages and the initial party-union relations. It will relate the variations in the organization of labor interests in Western Europe to distinct configurations in the extension of citizenship rights to labor and its national integration.

The aim is to refresh the study of union development by injections of theory and methods from comparative political sociology, in particular, by applying the cleavage analysis of party systems to union movements." However, one of the problems in applying a thesis on party systems to union movements is related to the more complex organizational structure of labor unions. Unlike a centralized political party, a union movement is an alliance that is composed not of one organization, but of a loosely coupled network of relatively autonomous affiliates that are incompletely coordinated by a higher order peak association: the union center. ${ }^{6}$ One of the pitfalls of political analysis has been to compare - too naively union centers and the allied party, disregarding the large heterogeneity within a union movement.?

4 Aristide R. Zolberg, "How Many Exceptionalisms?", in Ira Katznelson and Aristide R. Zolberg (eds), Working-Class Formation: Nineteenth-Century Patterns in Western Europe and the United States (Princeton, 1986), pp. 397-455.

'See the seminal contribution by Seymour Martin Lipset and Stein Rokkan, "Cleavage Structures, Party Systems, and Voter Alignments: An Introduction", in Seymour Martin Lipset and Stein Rokkan (eds), Panty Systems and Voter Alignments, Cross-National Perspectives (New York, 1967), pp. 1-64; and also Stein Rokkan, "Nation-Building, Cleavage Formation and the Structuring of Mass Politics", Comparative Studies in Socien" and History, 10 (1968), pp. 173-210; both articles are merged in Stein Rokkan et al., Citizens, Elections, Parties: Approaches to the Comparative Study of the Process of Development (Oslo, 1970), ch. 3.

"I use throughout the paper the term "union center" to denote various forms of peak associations of labor unions, such as union commissions, congresses, central organizations, or confederations (or federations, in American usage), with varying degrees of centralization and power.

' For an excellent historical comparison of selected sector unions see Gary Marks, Unions in Politics: Britain, Germany, and the United States in the Nineteenth and Early Twentieth Ceñtury (Princeton, 1959). 
I shall focus here mainly on the formation of political union cleavages and of the long-term party-union relations, comparing different configurations in the extension of citizenship rights which shaped the organization of labor interests. The concept of citizenship rights, some forty years after Marshall's seminal lecture, ${ }^{8}$ has gained in currency in the academic debate on the development of welfare states and liberal democracies. This paper looks from a somewhat different angle at how citizenship rights, particularly collective rights, delineate the opportunity structure of organized labor. The main idea is that at an early stage, the opportunity structure for the first mobilizing agencies was set with long-term consequences, ${ }^{9}$ and that the particular sequencing in the opening up of citizenship rights shaped the formation of party and unions and their interrelations. Reintroducing the concepts of social integration and system integration, ${ }^{10}$ I shall point at different configurations in the national integration of labor into polity, economy and society. ${ }^{11}$

A number of organizational theories support the assumption of the importance of the formation phase for later organizational development. Like the freezing hypothesis in political sociology, ${ }^{12}$ organization sociologists stress the importance of the institutionalization of the organizational structure at the time of founding and early consolidation. ${ }^{13}$ The organization's internal structure and its relationship with the environment as they were at the time of foundation are "socially imprinted" and later are difficult to dislocate, given sunk costs through past investments, vested interests in established structures, and comparative advantages to first mobilizing agencies. ${ }^{14}$ For various reasons, organizations once

T.H. Marshall, Citizenship and Social Class. The Marshall Lectures (Cambridge, 1950).

- Stein Rokkan, "Towards a Generalized Concept of Verzuiling: A Preliminary Note", Political Studies, 25 (1977), pp. 563-570.

${ }^{10}$ The two concepts were distinguished by David Lockwood, "Social Integration and System Integration", in G.K. Zollschan and W. Hirsch (eds), Explorations in Social Change (London, 1964), pp. 244-257; for a discussion and application to collective action problems see Wolfgang Streeck, "Vielfalt und Interdependenz: Überlegungen zur Rolle von intermediăren Organisationen in sich ändernden Umwelten", Kölner Zeitschrift für Soziologie und Sozialpsychologie, 39 (1987), pp. 471-495.

"For a historical comparison of various indicators on pre-war "national integration" of the working class see Marcel van der Linden, "The National Integration of European Working Classes (1871-1914): Exploring the Causal Configuration", International Review of Social History, 33 (1988), pp. 285-311.

"The freezing hypothesis postulated that "the party systems of the 1960's reflect, with few "but significant exceptions, the cleavage structures of the 1920's [ital. in orig.]": Lipset and Rokkan, "Cleavage Structures", p. 50.

${ }^{13}$ See, for a recent approach in organizational sociology and application to American labor unions, Mlichael T. Hannan and John Freeman, Organizational Ecology (Cambridge. MA, 1989).

"See especially Arthur L. Stinchcombe, "Social Structure and Organizations", in J.G. March (ed.), Handbook of Organizations (Chicago, 1965), pp. 142-193; and Constructing Social Theories (New York, 1968), pp. 101-129. 
institutionalized tend to "structural inertia", is resisting radical changes in their internal or external structure. This approach assumes that the particular forms of interest organization became institutionalized at an earlier time, at the time of founding and consolidation. Here, it is used as a heuristic tool to explore the origins of these social institutions: how far have the party and unions been marked by the context of their emergence?

This is not to rule out change. However, organizational adaptations to given challenges are contingent on the institutionalized organizational formation and external relations. Even though organizations may adapt to changing environments by strategic decisions at critical junctures, the claim is that "developments or decisions at one step set conditions or constraints for the next". ${ }^{16}$ The scope of organizational alternatives is constrained by organizational power relations and structural requirements that have been shaped by former decisions. ${ }^{17}$ Even though social, political and economic changes may alter the context in which these organizations initially emerged, their organizational structure, once institutionalized, remains an obstacle to profound and immediate change. Although the established organizations may be challenged by new interest groupings, they are normally able to survive through partial adaptation and exploitation of institutionalized links. A part of the past success and recent crisis of established cleavage organizations is rooted in their ability to reinforce social segmentations and organizational pillarization. ${ }^{18}$

I shall first present a model of the differentiation of labor party and unions as social institutions that accounts for both the context in which,

is Michael T. Hannan and John Freeman, "Structural Inertia and Organizational Change", American Sociological Review, 49 (1984), pp. 149-164.

${ }^{16}$ Rokkan, "Verzuiling", p. 564.

17 The argument connects with the insights from institutional economics and rational choice theory. The trajectories of organizational adaptations are path-dependent, see - most prominently - Douglas C. North, Institutions, Institutional Change and Economic Performance (Cambridge, 1990); they are limited by the institutionalized structures, the established vested interests, the past mobilization of cleavages, and the interplay of existing organizations. Seen in the perspective of rational choice, strategic decisions follow a "nested game", they are not necessarily the most optimal rational strategy of adaptation but are the result of a sequence of decisions. See especially George Tsebelis, Nested Games: Rational Choice in Comparative Politics (Berkeley, 1990); for an application to left-wing parties see Thomas A. Koelble, "Recasting Social Democracy in Europe: A Nested Games Explanation of Strategic Adjustment in Political Parties", Politics and Society, 20 (1992), pp. 51-70.

${ }_{18}$ I shall attempt to extend the insights from the literature on verzuiling (pillarization), to a general theory of cleavage persistence, following Rokkan, "Verzuiling"; cf. especially Gerhard Lehmbruch, Proporzdemokratie: Politisches System und politische Kultur in der Schweiz und in Osterreich (Tübingen, 1967); Arend Lijphart, The Politics of Accommodation: Pluralism and Democracy in the Netherlands (Berkeley, 1968); and Val R. Lorwin, "Segmented Pluralism: Ideological Cleavages and Political Cohesion in the Smaller European Democracies", Comparative Politics, 3 (1971), pp. 141-175; for historical comparison 
and the pattern by which, party and unions became differentiated and interdependent. The variations in the extension of citizenship rights to labor will be plotted and its impact on labor's national integration discussed. Thereafter I will compare three different cleavage "families" that led to politico-religious segmentation in union movements: the Socialist, Christian, and Communist labor movements. ${ }^{19}$ Such a cleavage analysis of labor movements provides a more differentiated view of party-union relations than past accounts which concentrate on one political movement only, such as the Socialist labor movement. ${ }^{20}$ However, this paper can only provide a brief, general survey on the formation of political union cleavages and party-union relations. It compares twelve Western European societies that are similar but differ in party-union relations and their particular trajectories. ${ }^{21}$ Finally this paper will plot the variations in political union cleavages and link these with different party-union relations across Europe. The focus remains on the formation process and not on the question of continuity and change that need further exploration and evaluation. The processes by which these political cleavages and party-union relations persist despite social and economic change can only be briefly mentioned, though they are discussed elsewhere. ${ }^{22}$

\section{AN ANATOMY OF THE SIAMESE TWINS}

Like Siamese twins, working-class party and labor unions were formed as two "wings" of the same social movement. Both organizational forms

of Catholic and Socialist pillars see Staf Hellemans, Strijd om de moderniteit: Sociale bewegingen en verzuiling in Europa sinds 1800 (Leuven, 1990).

${ }^{19}$ Although there are a number of other, minor currents in Western European labor movements, the three cleavage "families" are the most important; see for a detailed analysis Bernhard Ebbinghaus, Labour Unity in Union Diversity: Trade Unions and Social Cleavages in Western Europe, 1890-1989 (Ph.D., European University Institute, Florence, 1993), chs 3-5 and (on the salience of cleavages) ch. 9.

${ }^{20}$ The approach taken here departs from the instructive cleavage analysis of Stefano Bartolini, "I primi movimenti socialisti in Europa: Consolidamento organizzativo e mobilitazione politica", Rivista Italiana di Scienza Politica, 23 (1993), pp. 217-281; and also Stefano Bartolini and Peter Mair, Identity, Competition, and Electoral Availability: The Stabilization of European Electorates 1885-1985 (Cambridge, 1990). The two studies look mainly at the "left" bloc, and less at the intra-class fragmentation of labor, as initially . inherent in Rokkan's multi-dimensional cleavage analysis.

${ }^{21}$ These countries are (and are abbreviated in tables as follows) AU (Austria), BE (Belgium), DE (Denmark), FR (France), GE (Germany), IR (Ireland), IT (Italy), NE (the Netherlands), NO (Norway), SW (Sweden), SZ (Switzerland), UK (United Kingdom); the major omissions being Finland, Spain and Portugal, all latter three countries with important syndicalist-Communist traditions, and with longer authoritarian regimes.

22 See Bernhard Ebbinghaus, "From Ideology to Organization", in Patrick Pasture and Johan Verberckmoes (eds), The Lost Perspective? Ideology and Trade Unions in Europe (Aldershot, forthcoming 1995). 
resulted from a differentiation process of political and economic interest representation. Since we are accustomed to today's separation into the political system and industrial relations, we have to go back in time (or look at post-communist labor movements in Eastern Europe) to find examples of the initial fusion of party and union functions. To understand the "anatomy" of the Siamese twins, we need to analyze the context under which labor party and unions emerged. What conditions led to the formation of organized labor, and how did these conditions affect the differentiation between the Siamese twins and their relations?

The working-class party and labor unions, once established as separate organizations, may still have many reasons to maintain a close relationship, at least during their formation and consolidation phase. First, because both organizations claim to represent, attempt to mobilize and recruit from, the same social base (the working class), they will face questions of compatibility, if not competition, over resources that call for coordination. Second, each organization will be more or less compelled to rely on the other to achieve its aim, since some objectives can only be reached if cooperation in the other arena is secured. Unions gain from an alliance with the party which can press for legislation in their favor, and the party may call on the union to back its social and economic policies. For various reasons, the party-union linkage and the two forms of organizations tend to remain largely inert, yet they increasingly come under tension from the changing political, economic and social environment.

\section{TWO BERTHS OF THE SIAMESE TWINS}

The Siamese twins, labor party and unions,-were conceived - so to speak - in separate berths: the political and corporate arenas. Today, each social institution performs a different function and mobilizes in a different arena, though this is only the result of a differentiation process of political versus economic interest representation. From a "dissident" social movement that combined political and economic demands, labor party and unions emerged as separate interest organizations. They became drawn into two increasingly differentiated and institutionalized arenas of interest representation, in Stein Rokkan's words: the "electoral channel" and the "corporate channel". ${ }^{23}$ Whereas the electoral channel

23 My analysis follows Rokkan's call for a parallel study of political parties and labor unions: "In fact in one of my early articles on Norwegian developments I called for the analysis of the parallels and the interactions between two sets of organization-building efforts: the structuring of alternatives in what I called the 'numerical democracy' channel and the building of effective units of action in the corporate bargaining channel. [. . .] A full-fledged model would have to generate hypotheses not only about the emergence of alternatives in the electoral channel but also about the structuring of mass organizations in the corporate channels and about types of interlinkages between the units in the two arenas [ital. in orig.]." Rokkan "Verzuiling", p. 563; also Stein Rokkan, "Norway: Numer- 
provides the institutional means for citizens to influence politics and state action, the corporate channel regulates the use of organizational power in the relations between social groups (especially organized labor and capital), although the state may intervene in their self-regulation. According to this model, the political conflicts become increasingly "channeled" via party politics and expressed most importantly in elections, while labor relations are primarily settled through interest intermediation between employers and workers (especially through their organizations) at the workplace, the industry level or nationally, albeit often with tacit or explicit state involvement. As political and socialeconomic conflicts become increasingly institutionalized into different channels, the two arenas - the political system and labor relations - will also become more interdependent, as is most apparent in neo-corporatist arrangements of "political exchange" and state-society relations. ${ }^{24}$

According to the Rokkanean view, the differentiation of labor party and unions was shaped by the rise of liberal mass democracy and pluralist industrial capitalism. Historically, labor party and unions were founded and consolidated at about the same time, the pre-war decades in which the labor movement fought for universal suffrage and collective bargaining. The paths of political and corporate integration, in their sequence, timing and scope, molded the way in which working-class party and unions were formed, became separated and independent from each other. ${ }^{25}$

As S.M. Lipset observes, there is ample cross-national variation in the two paths by which "the working classes were accepted into the fabric of societies as political and industrial citizens. The first involves their right to vote and to organize a political party that could play a constructive role in the polity; the second refers to the way working-class economic combinations, in the form of labor unions, were accepted as formally legitimate by the state and substantively legitimate by employers". ${ }^{26}$ Thus the timing and structuring of these two channels had important consequences for the integration of labor into the bourgeois democracy and the capitalist welfare state. ${ }^{27}$ In particular, we find varying

ical Democracy and Corporate Pluralism", in Robert A. Dahl (ed.), Political Oppositions in Western Democracies (New Haven, 1966), pp. 70-115.

${ }^{24}$ See Colin Crouch, Industrial Relations and European State Traditions (Oxford, 1993), chs 9 and 10.

2s See Rokkan, "Nation-Building"; Kjell A. Eliassen, "Politische Beteiligung und parteipolitische Bindung der Gewerkschaften in Westeuropa: ein Uberblick", Soziale Welt, 25 -(1974), pp. 71-90; William M. Lafferty, Economic Development and the Response of Labor in Scandinvia: A Multi-Level Analysis (Oslo, 1971); and Seymour Martin Lipset, "Radicalism or Reformism: The Sources of Working-class Politics", American Political Science Review, 77 (1983), pp. 1-18.

${ }^{26}$ Lipset, "Radicalism or Reformism", p. 6.

27 On integration into the welfare state see Peter Flora, "Introduction", in Peter Flora (ed.), Growth to Limits: The Western European Welfare States Since World War II (Berlin, 1986), vol. I, pp. 11-36. 


\begin{tabular}{|c|c|c|}
\hline Electoral channel & Interest intermediation & Corporate channel \\
\hline $\begin{array}{l}\text { "National Revolution" } \\
\text { Transition to } \\
\text { political democracy: } \\
\text { 1) Legitimation } \\
\text { 2) Incorporation } \\
\text { 3) Representation } \\
\text { 4) Executive power } \\
\text { PAF }\end{array}$ & $\begin{array}{l}\text { Working-class formation } \\
\text { Labor movement } \\
\leftarrow \text { differentiation } \rightarrow \\
\text { Political Economic } \\
\text { functions functions } \\
\leftrightarrow \text { interdependence } \leftrightarrow\end{array}$ & $\begin{array}{r}\text { "Industrial Revolution" } \\
\text { Transition to } \\
\text { economic democracy: } \\
\text { 1) Coalition right } \\
\text { 2) Action right } \\
\text { 3) Bargaining } \\
\text { 4) Participation }\end{array}$ \\
\hline Political integration & & Corporate integration \\
\hline STATE & LABOR & EMPLOYERS \\
\hline
\end{tabular}

Figure 1. Model of party-union differentiation in the electoral and corporate channel

elite strategies toward an extension of (in T.H. Marshall's wording) civil, political, and social citizenship rights to the lower classes. ${ }^{28}$

These citizenship rights delineated the "opportunity structure" for the organization of labor interests. ${ }^{29}$ Hence, the national state opened up, earlier or later, gradually or suddenly, new opportunities for collective action and representation of labor interests. They go beyond individual citizenship rights and also entail, and most notably for labor, collective rights. The granting of these citizenship rights was an interaction between elite strategies and contentious collective action by the political contenders. In practice it was often a spiral of contention and counteraction by the labor movement and the power-holders in polity and society. Here, we will take these as given and exogenous, yet ask how these varying opportunities shaped the formation of party and unions, and their interrelations (see Figure 1). ${ }^{30}$

${ }^{28}$ For an elite strategy perspective and critical appraisals of Marshall, "Citizenship", see especially Anthony Giddens, The Nation-State and Violence (Cambridge, 1985); Michael Mann, "Ruling Class Strategies and Citizenship", Sociology, 21 (1987), pp. 339-354; and The Sources of Social Power: Vol. II, The Rise of Classes and Nation-states, 1760-1914 (Oxford, 1993). Marshall's citizenship rights and Rokkan's threshold model have an evolutionary bias as they tend to generalize from the British case. As Giddens and Mann point out, citizenship rights have not come "naturally" but were achieved by political struggle, albeit only partly by class struggle.

${ }^{29}$ See the classical statement by Ralf Dahrendorf, Class and Class Conflict in Industrial Society (Stanford, 1959), p. 183; and for mobilization theory, see especially Charles Tilly, From Mobilization to Revolution (Reading, 1978), ch. 4.

${ }^{30}$ I will not discuss explanations for the varying elite strategies, nor their impact on the development or stability of mass democracies, as this has been the subject of an extended debate in political sociology. Beside the above cited work of Rokkan, Lipset and Mann, see Reinhard Bendix, Nation-Building and Citizenship, (new ed., Berkeley, 1977; 1st pub. 1964); Seymour Martin Lipset, Political Man: The Social Bases of Politics (New York, 1960); Gregory M. Luebbert, Liberalism, Fascism, or Social Democracy: Social Classes and the Political Origins of Regimes in Interwar Europe (New York, 1991); John' D. 
Following Rokkan ${ }^{31}$ one can postulate four institutional thresholds that structured the political integration of the working class into the polity: (1) The threshold of legitimation: when were formerly excluded social groups granted the rights to assemble, to become organized and to express themselves in public? (2) The threshold of incorporation: when were these groups allowed to participate in political representative bodies? (3) The threshold of representation: when was a proportionality between electoral power and decision-making power established? (4) The threshold of executive power: when did these groups get the chance to participate in the execution of government? These intervening constraints molded the "political alternatives" available to the labor movement in forming its political organization.

A similar set of four thresholds can be proposed with respect to the transition toward a pluralist system of industrial relations in the "corporate" channel: ${ }^{32}$ (1) The threshold of coalition right: when was the right to form coalition of labor granted and no longer impeded? (2) The threshold of collective action: when was the right to strike granted to all workers? (3) The threshold of bargaining: when were unions recognized as collective bargaining partners by the state and by employers? (4) The threshold of participation: when did unions became intermediary organizations involved in the formation and execution of social policy and economic management? These thresholds constrained the "alternatives" of union organization and the form and degree of organized labor's integration into the capitalist economy. ${ }^{33}$

These ideal-typical threshold models idealize the stepwise, sequential processes of political and corporate integration. The deviations from the evolutionary path point at different opportunity structures for the formation of organized labor. In some societies, labor faced higher hurdles than in others while climbing the ladder toward political and industrial democracy. The two processes were not always parallel and synchronic, thus opportunities for collective action were opened in one, while closed in the other channel. Certainly, to give a brief summary of the long

Stephens, "Democratic Transition and Breakdown in Europe, 1870-1939: A Test of the Moore Thesis", American Journal of Sociology, 94 (1989), pp. 1019-1077; Göran Therborn, "The Rule of Capital and the Rise of Democracy", New Left Review, 103 (1977), pp.3-41.

${ }^{31}$ Rokkan, Citizens, Elections, Parties, p. 79.

32 Ebbinghaus, Labour Unity, ch. 2.

${ }^{33}$ Few studies have systematically analyzed the variations in industrial relations. For an account of the transition to industrial democracy, see Amdt Sorge, "The Evolution of Industrial Democracy in the Countries of the European Community", British Journal of Industrial Relations, 14 (1976), pp. 274-294; for a recent study on state-society relations, see Crouch, Industrial Relations; and for informative overviews on state intervention in industrial relations, see Klaus Armingeon, Staat und Arbeitsbeziehungen: Ein internationaler Vergleich (Opladen, 1994); and Bob Hepple (ed.), The Making of Labour Law in Europe: A Comparative Study of Nine Countries up to 1945 (London, 1986). 
struggle for political and industrial citizenship by delineating a few decisive steps (and time points) remains a difficult task. ${ }^{34}$

\section{EARLY CITIZENSHIP RIGHTS FOR LABOR}

The first crucial step was the granting of association and coalition rights by the national states to their citizens, that is the legalization of collective organization for political and economic interests. Both collective rights were introduced relatively early after the bourgeois revolutions (or revolts) in Britain (1820s), France (1830), Belgium (1831), Denmark (1848), Switzerland (1848), but also in Norway (1838) and the Netherlands (1855) - bringing more political and economic freedoms to the bourgeois classes (see Table 1). However, with increasing industrial conflicts, the right for workers to form a coalition was either limited or repealed for some time in France, Belgium and Denmark, when more authoritarian regimes ruled. Britain, France and Belgium were also among the first to abolish the guilds as early as the 1830s (in France coalitions were banned as early as 1791) and the Scandinavian nations followed in the 1860s. The other continental European countries, however, continued to some degree with the corporatist legacies at local level, not to mention the Chamber structures in Austria and Prussia. On the other hand, in France and countries with Code Napoleon legal traditions (particularly Belgium) not only guilds but any coalition for special interests was abolished (Chapelier law); for a long time this put a toll on the organization of capital and especially labor until its repeal (in France: 1884). The right to form political associations or even workers' coalitions was granted much later and with more authoritarian restrictions in Sweden (1864), Austria (1867/1870), Germany (1869/1871) and Italy (1890), and the coalition ban was again imposed in Germany (1878-1890) and Austria (1864-1891) under the anti-socialist authoritarian regimes of Bismarck and Taaffe.

Despite the particular developments, there are two main variants in the legitimation of political and economic interest representation: political and economic liberal regimes with undisputed and early introduction and authoritarian regimes with a more repressive and belated extension of these rights. Moreover, we find for both regimes variations as to the bias toward individual and collective rights, and thus one can distinguish at least four different regimes: (1) liberalist laissez-faire regimes, most notably England, where association and coalition rights were granted to individuals as long as they did not impede the free market principles,

\footnotetext{
${ }^{34}$ Note that these processes were often long enduring, far from clear-cut, and even sometimes reversed. Moreover, these rights were only rarely explicitly and fully guaranteed, their practical value depends on juridical application, administrative practice, and other facilitating circumstances. How precarious these rights were, was shown more than once - when authoritarian regimes repealed fundamental rights with one stroke.
} 


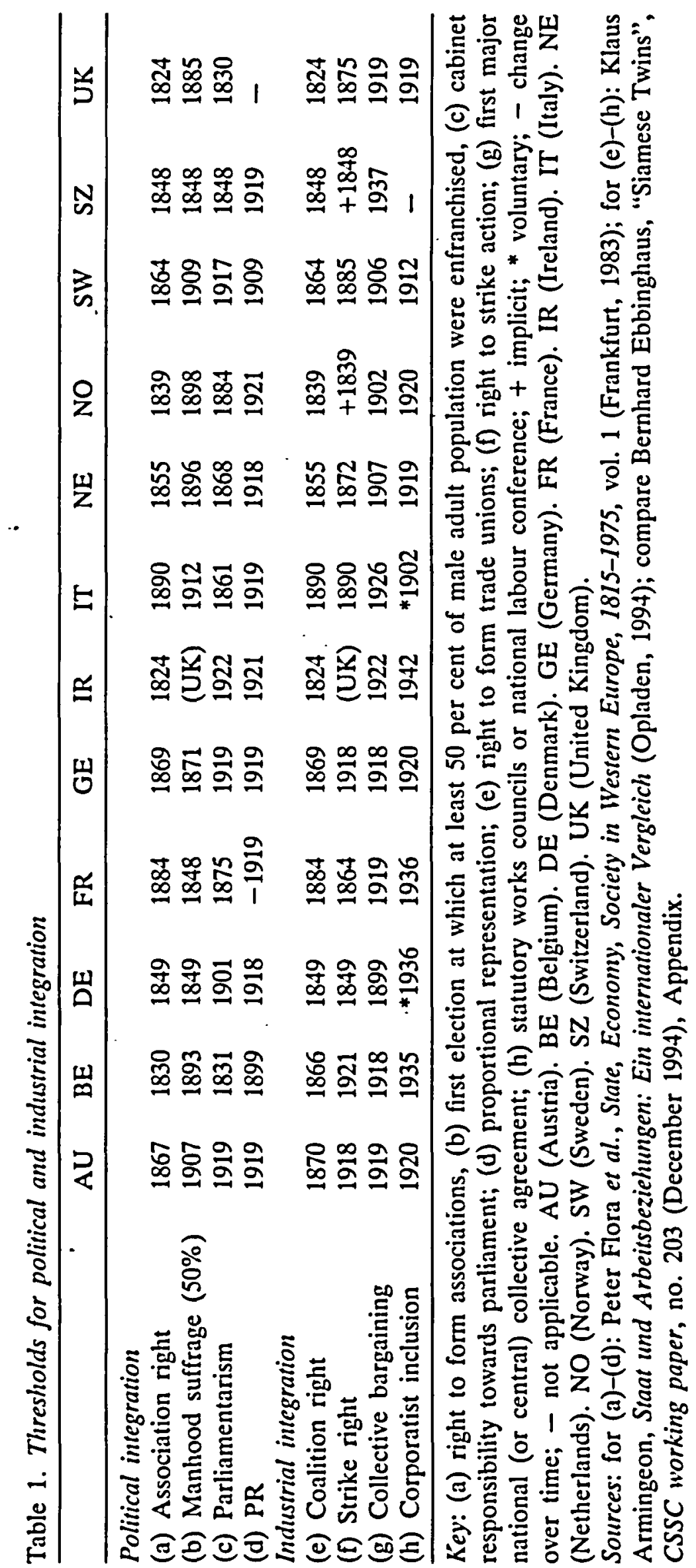


and (2) liberal-consociational states where pre-capitalist Ständestaat forms of representation and modern association rights coalesce, like Switzerland or the Netherlands. Among the authoritarian regimes, there were (3) authoritarian-bourgeois regimes that granted political rights and. withheld coalition rights for the lower classes, like Belgium and France after the 1850s, while (4) authoritarian dualist monarchies limited and retarded political and coalition rights, though given their Ständestaat legacies they cultivated non-political corporate Kammer representation, in particular Austria and Prussia. ${ }^{35}$

Even more important was the second threshold: the extension of suffrage and the establishment of strike rights. Both rights impinge directly on the mobilization strategies and the long-term strategy toward electoral and industrial democracy. ${ }^{36}$ Of particular importance for the integration of labor into the polity was the sudden or gradual, the early or belated introduction of universal suffrage. The crucial step was the manhood suffrage reforms, since woman suffrage was not necessarily to the initial advantage of organized labor, as women tended to be less frequently employed as industrial workers and tended to vote for religious parties where these existed. Following World War I, all Western European democracies had introduced universal at least manhood if not woman suffrage, but from then on the past formation of mass political parties tended to be frozen in the saturated electoral market. ${ }^{37}$ Thus the timing and character of the early extension, the way in which the lower classes were allowed to participate in elections was crucial.

Given the sometimes gradual, sometimes stepwise extension of the suffrage, it is difficult to compare diachronically suffrage reforms. When we look at an arbitrarily chosen threshold of 50 per cent of the male population at legal voting age, that is, a franchise extension from which at least larger sections of the working class profited, we find considerable variation. The earliest extensions were those of France, Switzerland and Denmark, countries in which sections of the emerging working class were already enfranchised before organized labor emerged. After the German unification, the new Imperial diet (with little federal power)

35 See Crouch, Industrial Relations, p. 320.

36 The suffrage extension has been the subject of many comparative studies on the mass democracies, often leading to different evaluations depending on the definition of democracy, cf., for example, the diverging classification of the United States of America by Lipset, "Reformism or Radicalism", and Therborn, "Rule of Capital", as early and late introducers of universal suffrage respectively; for a valuable historical overview see Jürgen Kohl, "Zur langfristigen Entwicklung der politischen Partizipation in Westeuropa", in P. Steinbach (ed.), Probleme politischer Partizipation im Modernisienungsproze $\beta$ (Stuttgart, 1982), pp. 473-503.

${ }^{37}$ Lipset and Rokkan postulate "the rule that the parties which were able to establish mass organizations and entrench themselves in the local government structures before the final drive toward maximal mobilization have proved the most viable": "Cleavage Structures", p. 51. 
was elected on an equal manhood suffrage (1871), albeit the largest state (Prussia) retained the old three-class system. Whereas in the four countries universal suffrage was granted prior to coalition rights, there is otherwise a rather linear relationship between the extension of both rights. ${ }^{38}$

A late and sudden reform was introduced only after the turn of the century in Austria (1907), Sweden (1909), Italy (1912) and Prussia (1918), while in the Low Countries a partial suffrage reform was introduced in the 1890 s - many years after the association right. In these countries, the labor movement mobilized around the question of suffrage and electoral reform - international signs of this were the general strikes for suffrage reforms in Belgium and Sweden in 1902, albeit without immediate success. The German and Danish marches toward social-democratic electoral success nurtured the "Great Expectation" of the labor parties eventually to win an electoral majority. ${ }^{39}$ The labor unions in turn hoped to gain from an increase in electoral power of their political ally which could eventually undo the restrictions on coalition, strike and bargaining rights for organized labor. Thus the political citizenship rights also molded the unions' political action and alliance strategies.

The strike right was the twin mobilization device for organized labor the opportunity to gain in collective industrial power which would complement the electoral march. Again the universal breakthrough came with the democratic changes after World War I, when the strike right was fully granted in all Western European democracies, though partly excluding civil servants. The early introduction of (largely implicit) strike rights was again the early fruit of the liberal bourgeois democratization in Norway (1839), Switzerland (1848) and Denmark (1849), while incremental steps were undertaken in Britain (1824/1875), Sweden (1846/ 1864) and the Netherlands (1848/1872).

Only belatedly and partially did Germany and France introduce coalition and strike rights, much later than universal manhood suffrage. Austria (1870), Belgium (1866) and Italy (1890) had made some moves, but the explicit strike right was enshrined only with the inter-war constitutions. Following the reversal of democracy, the coalition and strike rights were repealed immediately by Fascist Italy (1922-1944), Nazi Germany (1933-1945), authoritarian (later Fascist) Austria (1934-1945) and elsewhere under German war occupation. The withholding of the strike right was less a toll on contentious collective action but on the way in which organized labor could press employers and the state to make concessions. The legality of strikes (but also lock-outs) and the character

${ }^{38}$ Charles Tilly, "Globalization Threatens Labor's Rights", International Labor and Working-class History, 47 (1995), pp. 1-23.

39 Adam Przeworski and John Sprague, Paper Stones. A History of Electoral Socialism (Chicago, 1988; 1st pub. 1986). 
of state repression of industrial conflict shaped the long-term strategies of labor and led to the more relentlessly violent eruptions or to smoother institutionalization of the class conflict.

\section{THE INSTITUTIONALIZATION OF ORGANIZED LABOR}

Once the first citizenship rights were established, once workers had the right to form their own parties and unions and to express their interests and grievances via elections and industrial action, the next crucial step was the institutionalization of their interest organizations in the political decision-making and the self-regulation of labor relations. The following two thresholds thus go beyond individual citizenship rights and define the institutions and the "rules of the game" of political and economic interest intermediation from which workers gain only indirectly through their organizations. Thus in the course of a century we witness a shift from the guarantee of basic citizenship rights of labor towards the institutionalization of organized labor's collective rights in the electoral and corporate channels.

The third threshold in the "corporate" channel delineated the degree to which the class conflict became institutionalized through an emerging system of collective bargaining and mutual recognition between the "social partners". The pre-war strike waves (and increased power of organized labor) also provided an impetus to employer organization and centralization..$^{40}$ It furthered early forms of state arbitration of industrial conflicts and labor courts. ${ }^{41}$ These changes in employer organization and state intervention in industrial relations were in turn conditions for the development of nation-wide collective bargaining around the time of World War I.

Early advancement of national bargaining and union recognition were made most prominently in Denmark where the first national bipartite agreement was signed as early as 1899 , followed by breakthroughs in the other Scandinavian countries (Norway 1902, Sweden 1909), or the early recognition of employment contracts in the Netherlands (1907). In a number of other countries, particularly Britain, collective bargaining had made considerable headway in some industries before 1914, though national agreement and mutual recognition was only advanced through the war, as in most continental countries. A truly national understanding of the paternalist employers and radicalized unions was retarded in France, Italy and Switzerland. After long paternalist intransigence national agreement was thrust upon employers under the pressures from

\footnotetext{
* For a historical comparison of British and Swedish organized interests see James Fulcher, "On the Explanation of Industrial Relations Diversity: Labour Movements, Employers and the State in Britain and Sweden"; British Journal of Industrial Relations, 26 (1988), pp. 246-274.

${ }^{41}$ Armingeon, Staat und Arbeitsbeziehungen.
} 
the "street" during the French Popular Front and the explicit force of Italian Fascist corporatism. The need for domestic peace at a time of international war threat induced Swiss employers and organized labor in the manufacturing sector to sign the Friedensabkommen ("peace" pact) that still is the base of settling labor disputes. The breakthrough in national collective bargaining is the third phase in which organized labor's role became recognized as a durable and recurring bargaining partner, since then, and given the earlier strike right, the mere threat of collective action (based on labor's organizational strength) could translate into real bargaining power. The recognition of labor unions as a bargaining partner also marks the shift from "classic" workers' combinations towards befestigte (established) union organizations. ${ }^{42}$

The fourth threshold in the corporate channel, the corporatist inclusion, is the timing and degree to which labor became integrated into the management of social and economic policy at the workplace, the enterprise level, and/or the national economy. The variations in corporatist inclusion and industrial democracy are pronounced, varying in the degree of state intervention or liberalist laissez-faire, but also in the continuity of voluntary practices or corporatist Ständestaat legacies. ${ }^{43}$ In liberal laisez-faire democracies, like Britain, forms of workplace representation and even national conciliation remained temporary and voluntary, that is, the result of union power or political initatives at a particular time. In Scandinavia, organized labor and capital with varying degrees of state help developed corporatist arrangements for self-regulation to preempt potential state intervention. In Ständestaat continental Europe, particularly in Germanic countries, corporatist institutions were more or less enshrined into labor law for the self-regulation of labor matters at multiple levels. The dualist worker participation forms, the elected statutory works councils, codetermination in large company boards, advisory Chambers of Labor, or other corporatist institutions were part of a strategy to appease and channel labor relations and disputes by delineating rights and duties of labor - independent of union or strike power. In consociational countries, these corporatist institutions were also part of a subsidarity strategy to enhance conciliation in political and socially segmented societies, while such efforts were retarded and incomplete in polarized societies, most notably in France and Italy. ${ }^{44}$

In the electoral channel, the third and fourth thresholds in Rokkan's model were important for the chance of organized labor to succeed on ,the "road to socialism". The introduction of proportionality (in particular proportional representation) and of parliamentarism (responsibility of

\footnotetext{
42 See Götz Briefs, "Gewerkschaften", in Handwörterbuch der Sozialwissenschaften, vol. 4 (Tübingen, 1965), pp. 545-561.

${ }^{43}$ See Crouch; Industrial Relations; and Sorge, "Evolution of Industrial Democracy".

4t See Lorwin, "Segmented Pluralism".
} 
the government to parliamentary majorities of the lower house) were preconditions for the fulfillment of the "Great Expectation" of the working classes to win a parliamentary and government majority in the long run. The paths toward the realization of these principles were again varied, partly a reflection of the endangerment of the ruling coalitions through an enlarged franchise. The reasons that led to early or late, substantial or unequal representation are varied and part of the political history of democratization.

More important for the development of party-union relations within the labor movement remains the impact of these political changes on the actual chances of organized labor to become a substantial force (or opposition) in parliament and the timing (but also length and weight) of government participation of labor parties. The earlier, the more stable, and the more significant the representation of working-class interests in parliament or even in government, the more we would expect labor parties to develop their own pragmatic independence and self-confidence vis-à-vis the unions and the more the union movement could count on a supportive political environment, even though it may come increasingly under tension with an incumbent labor party. ${ }^{45}$ In'the early phase, government participation of an allied political party helped the union movement to secure union rights and foster collective bargaining and corporatist institutions. Moreover, these parties would extend universal welfare policies that backed up and complemented social rights of workers which were secured through collective bargaining. However, once national Keynesian welfare state policies reached their internal and external limits to growth, given public spending constraints and global competition, the party-union relations became increasingly strained. ${ }^{46}$

\section{THE SEPARATION AND INTERDEPENDENCE OF THE SIAMESE TWINS}

The ideal-typical thresholds can be used to develop hypotheses about the impact of the political and corporate integration of the labor movement on the formation and separation of the Siamese twins. The political and corporate integration model (see Figure 1) allows us to delineate two dimensions: the degree of differentiation of the two channels and the sequencing in the opening of the two channels. In the case where the separation was earlier and more clear-cut, the more we expect labor party and unions to be differentiated and less dependent. Moreover, if the processes are neither gradual nor synchronous, we expect a "spillover" effect from the political into the economic arena, or vice versa. Thus if the political channel remains closed longer, one can expect a

4s See Taylor, Trade Unions and Politics; and Przeworski and Sprague, Paper Stones.

- ${ }^{4}$ See Fritz Scharpf, Sozialdemokratische Krisenpolitik in Europa (Frankfurt, 1987). 
"politicization" of the organizations in the corporate channel, mobilizing collective action for political change, while in the reverse case, unions will seek political alliance and support to make up for the lack of power in the labor market.

Both the working-class political party and labor unions, as organizations of previously excluded sections of the population, were initially "deviant" organizations, launched by "political inventors". ${ }^{47}$ These organizations were threatened by extinction if they were unable to consolidate and build an organizational structure based on membership support and organizational alliances. The sequencing and the degree of differentiation of political and economic interest intermediation accounts for a large share of the diversity in union movements across Western Europe. The crucial questions are: Which came first, the party or the unions? Which organization created and supported the other? Was the party sufficiently strong and able to shape the development of the union movement, or was the reverse true or was neither the case? The question of organizational legitimation is important for the understanding of partyunion relations. In his analysis of political parties Duverger distinguishes between internal and external founding. ${ }^{48}$ Externally legitimated organizations tend to be more entrenched in interorganizational networks and more resistant to immediate adaptation, while adaptation of internally legitimated organization will depend more on the authority of the central leadership and its unity.

Furthermore, the degree of centralization depends on the interorganizational relations and strategic choices of the leadership. Duverger assumed that the internally legitimated organizations would be more decentralized than those that were externally legitimated, though centralization and support are not always correlated. ${ }^{49}$ One should further distinguish two interacting forms of organizational consolidation: a strong, centripetal strategy of penetration, and a weak, centrifugal form of diffusion. ${ }^{\text {so }}$ In the former, it is the center that infuses the suborganizations with universal values and which are controlled from the

4 On "deviant" organizations see Birgitta Nedelmann, "Handlungsraum politischer Organisationen", Sozialwissenschaftliches Jahrbuch für Politik, 4 (1974), pp. 9-118; and on the role of "political inventors", Stinchcombe, "Social Structure and Organizations".

48 Maurice Duverger, Les partis politiques (Paris, 1953).

49 According to Duverger, externally founded organizations tend to be more centralized, they are formed top-down, thus with more hierarchical discipline, and the center assumes primary authority. In contrast, the loose electoral alliances or parliamentary groupings tend to be more decentralized; they have been formed bottom-up, and the local structures largely maintain their autonomy: see Duverger, Les partis politiques. Although they have often been historically coexistent, one should separate the dimension of legitimation from the degree of organizational consolidation (or centralization).

so Angelo Panebianco, Political Parties, Organization and Power (Cambridge, 1988); cf. Kjell A. Eliassen and Lars Svaasand, "The Formation of Mass Political Organizations: An Analytical Framework", Scandinavian Political Studies, 10 (1975), pp. 95-120. 
"top", whereas in the latter, a loose network of organizational units adapts a common ideology and forms an alliance from the "bottom-up". These four variations in organizational legitimation and consolidation have important consequences for the future ability to adapt because they constrain the corporate actor's autonomy to implement organizational reforms. An internally legitimated center-led organization (cadre party) is more likely to follow the rational calculations of its leadership than a decentralized organization (federalized party). An externally legitimated organization is more bound in its capacity to change (centralized labor party), but it may gain from support in the other channel, though this may be offset by decentralized structures (social movement party).

A similar logic of organizations can be applied to labor unions, however, taking into account the larger heterogenity of union movements. For instance, an internally legitimated and centralized political party has a greater capacity to adapt than a similarly formed union center, which encompasses greater internal heterogeneity. We would expect that a party-led union alliance is more centralized at the peak than a union federation with only internal legitimation. ${ }^{51}$

My claim is that the organizational legitimation and consolidation processes are fundamental in shaping long-term party-union relations. The institutionalized patterns of party-union differentiation and linkages later pose major obstacles to adopting and implementing organizational reform that may be imperative given exogenous social and political changes. ${ }^{52}$ Internal vested interests, strong external linkages or diffused organizational identity constrain the possibilities of reaching consent and, more importantly, implementing decisions uniformly. In the following section I shall sketch party and union formation, though mainly by focusing at apparent organizational differences and only indicating internal organizational aspects. ${ }^{53}$

\section{THREE CLEAVAGE FAMILIES OF SIAMESE TWINS}

The Siamese twins, the working-class party and allied union movement, have close links due to their similar social base, and both are derived

${ }^{51}$ For instance, the internally legitimated British TUC has been much less centralized than the party-led Swedish LO that was formed on the initiative and with the ideological assistance of the Socialist party: see James Fulcher, Labour Movements, Employers, and the State: Conflict and Co-operation in Britain and Sweden (Oxford, 1991).

52 See recently Herbert Kitschelt, The Transformation of European Social Democracy (New York, 1994); and Koelble, "Recasting Social Democracy".

${ }^{33}$ One encounters practical problems in accounting for internal organizational variations, if one does not choose a case study analysis (for example, see Marks, Unions in Politics) that highlights diverse cases but cannot map the general pattern. Moreover, only a few comparative organizational indicators and little systematic information are available to test this hypothesis; for an exception see Jelle Visser, In Search of Inclusive Unionism (Deventer, 1990), ch. 8. 
from the same labor-capital cleavage, the entrenched conflicts in polity and society over the rights of the dependent employed. We would expect both party and unions to emerge in tandem, if the political and corporate channel provide equal chances for interest representation of labor. It was observed that unlike other political party formations, working-class parties emerged in most cases shortly before the introduction of universal (or manhood) suffrage around the World War $\mathrm{I}^{54}$ Similarly seen from a long-term comparative perspective, we find the rise of union movements all over Western Europe before the institutionalization of collective bargaining in the inter-war period. ${ }^{55}$

However, there are two major variations in political unionism in Western Europe that warrant further study. First, the creation of the Siamese twins took shape in various forms, leading to variations in the institutionalization and differentiation of labor interests in the electoral and corporate channels. Second, in some societies other societal cleavages cross-cut the labor-capital cleavage which split labor interests into separate cleavage "families", with varying relations between party and labor unions. A study of the formation of party and unions and their relations within each cleavage "family" gives us a rich but complex picture of how labor interests became organized under diverse political and economic configurations.

If social and political cleavages lead to splits in one arena this will affect organized labor in the other. Indeed, the Socialist party and allied labor movement is not the sole organization representing the working class across Europe. In a number of countries Christian and Communist labor movements compete for workers' allegiance with the Socialist movement. Hence, like the party system, an understanding of the trade union system should be based on an analysis of the "transformation of cleavage structures" into interest organizations. Cleavages are potential lines of conflict that result from differences in the social structure and the mobilization of these conflicts by political or collective actors. Not all cleavages are necessarily politicized and find their organizational representation in each society. ${ }^{56}$

Following Rokkan's cleavage analysis, I will argue that there are three major "families" of Weltanschauung that gave rise to major schisms in the organization of labor interests. ${ }^{57}$ First, labor vs. capital cleavage: the

\footnotetext{
54 "Conflicts in the labor market, by contrast [to other cleavages], proved much more uniformly divisive: all countries of Western Europe developed lower-class mass parties at some point or other before World War One." Lipset and Rokkan, "Cleavage Structures", p. 35.

ss See the parallel argument to the Lipset and Rokkan thesis on party systems for labor unions by Bernhard Ebbinghaus and Jelle Visser, "Where Does Union Diversity Come From?", XIIth World Congress of Sociology (Madrid, July 1990).

56 Jan-Erik Lane and Savante O. Ersson, Politics and Society in Western Europe, 2nd. ed. (London, 1991), ch. 2.

57 Rokkan, Citizens, Elections, Parties; cf. Ebbinghaus, Labour Unity.
} 
formation of a Socialist political and economic movement that separated itself from reformist left Liberalism. Second, church vs. state cleavage: the formation of Christian Democratic parties and Christian trade union movements, a split in workers' alliance between secular socialist ideology and Christian beliefs. Third, revolution vs. reform cleavage: the formation of the Communist party and unions, a schism in the working-class movement into a national, reformist path and a revolutionary, internationalist path. The Siamese twins' relations play an important role within each cleavage "family". Moreover, the historical choices of previous cleavages shape the responses to other potential labor cleavages. They also structure the alternatives: the rise of separate cleavage organizations or the integration into existing organizations. We will now turn sequentially to each of these three cleavages discussing the formation period and the party-union relations.

\section{THE LABOR-CAPITAL CLEAVAGE}

In the course of the Industrial Revolution, the labor-capital cleavage led more or less uniformly to the formation of a working-class party and unions. Certainly, the Industrial Revolution spread unequally and with a varying pace from its birth in Britain across Europe, though the Arbeiterfrage, the social problems connected with the rise of industrial capitalism, became a pressing question on the political agenda in all countries. The ruling elites used varying maneuvers to exclude the working class from gaining full political participation, and to hamper its collective organization, while mending the most dangerous wounds of industrialization by partial social policy measures. ${ }^{58}$ Even though still a class in-the-making, the working class represented a substantial minority (one-fourth to one-third of the adult pre-war population) with the "Great Expectation" that it would become the ruling majority in the near future. ${ }^{59}$ Moreover, Socialist ideas, that adhered to the ultimate goal of a classless society, were disseminating internationally, thanks to improved communication patterns, transnational contacts and the exile of dissidents.

During this period of intensified capitalist industrialization and working-class formation Socialist parties emerged in Western Europe between 1863, when the first sister organization of the German Socialist party emerged, and 1893 when the British Independent Labour Party was formed (see Table 2).$^{60}$ Nevertheless, granted the universality of the

\$8 Flora, "Introduction".

59 Przeworski and Sprague, Paper Stones, pp. 25-28.

${ }^{60}$ In the following the term Socialist party and Socialist union movement is used as a general term for non-Communist working-class parties and union movements, though in some cases the terms Social-Democratic party, Labor party or Free union movement. are more appropriate. This is not to claim that all these working-class parties (or unions) are ideologically or sociologically similar, quite the contrary. 


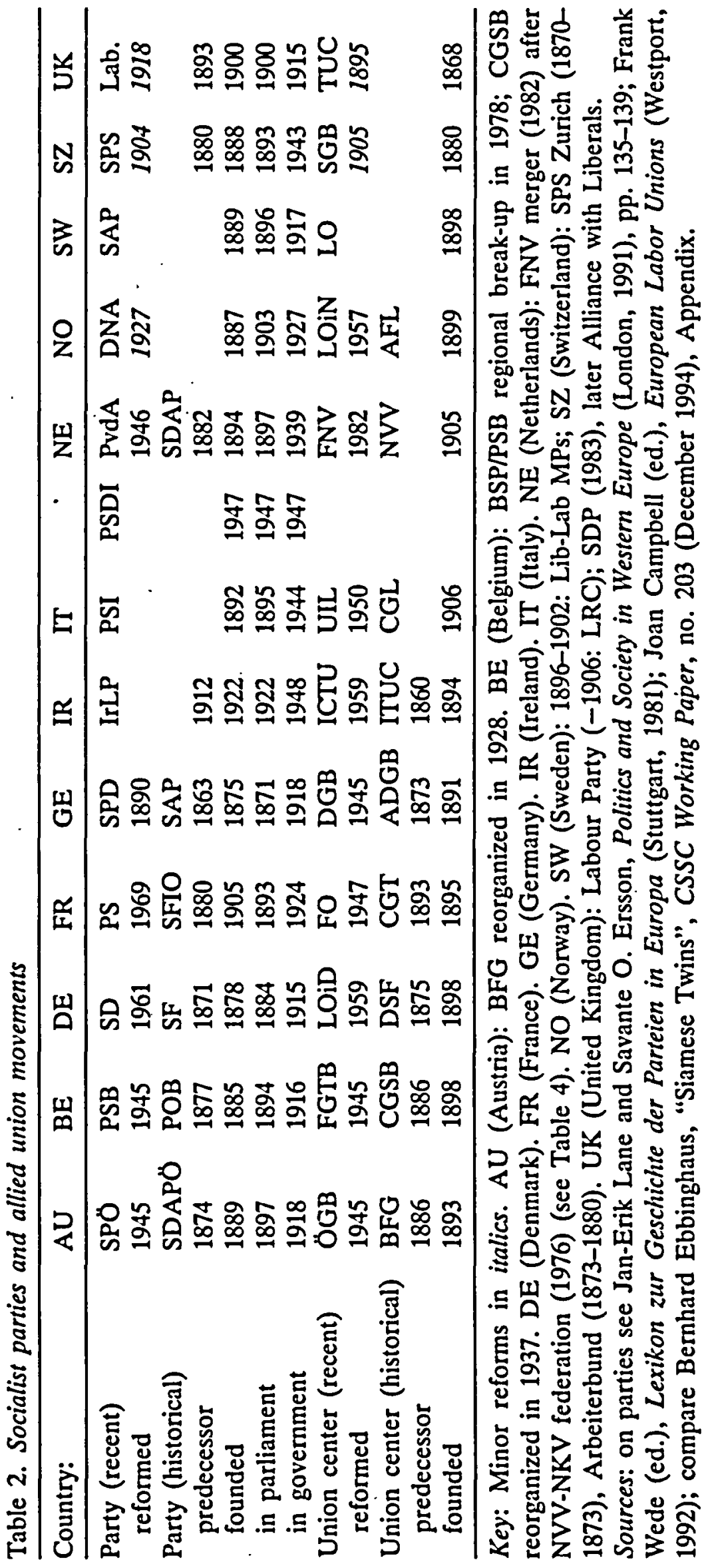


emergence of the labor-capital cleavage, the timing of these working-class parties, their organizational form and their electoral success varied considerably with important consequences for the labor movement in general. Union movements emerged partly synchronically, partly diachronically to Socialist parties, enhancing the diversity in union movements by various forms of party-union relations. The timing and sequence of integration into the political and economic systems shaped the development of party and unions alike. The initial relationship became entrenched, limiting the set of alternatives for adapting to change.

While the Socialist party had to integrate both parliamentary grouping and territorial party structures, the union movement had an even more difficult task in centralizing. National unions had to achieve authority over local unions in order to deal with the national integration of labor and product markets. National union centers attempted to integrate both functional and territorial forms of interest representation in order to press - with one voice - for improvements vis-à-vis the state and employers. In both struggles, the Socialist party played a crucial role, practically as .well as ideologically, by stressing class solidarity over sectionalism. ${ }^{6}$ Hence, the timing and sequence of party and union formation were crucial for the structure and orientation of the union movement. Four different ideal-typical patterns of sequencing, representing different combinations of legitimation and institutionalization (see Table 3), can be derived from a bird's-eye view of labor history. ${ }^{62}$

In the first case, the party preceded the union center, giving the union movement fostering national coordination and ideological equipment (in short: the Social-Democratic type). In these countries, a well-organized Socialist party (German SPD, Swedish SAP and Belgian POB) initially coordinated the local and national activities of unions. The party later initiated the founding of an allied union "secretariat", from which a fully fledged centralized union confederation emerged. Thus, an early centralized party molded the centralization of the union movement and the integration into national unions. The German Free union center was set up (1891) with the help of the party, and grew gradually in strength and self-assurance vis-à-vis the party. Yet the party still claimed its primacy over such contentious matters as the general strike until the 1906 settlement. In Sweden, the party coordinated union activities until

${ }^{61}$ See Fulcher, "Industrial Relations Diversity"; and Labour Movements, Employers, and the State, ch. 3.

62 On Socialist union confederations see Walter Galenson (ed.), Comparative Labor Movements (New York, 1968; 1st pub. 1952); Dick Geary (ed.), Labour and Socialist Movements in Europe before 1914 (Oxford, 1989); Walter Kendall, The Labour Movement in Europe (London, 1975); Marcel van der Linden and Jurgen Rojahn (eds), The Formation of Labour Movements 1870-1914, 2 vols (Leiden, 1990); and Visser, Inclusive Unionism. On Socialist parties see William E. Paterson and Alastair H. Thomas (eds), Social Democratic Parties in Western Europe (London, 1977); and "Future of Social Democracy". 
Table 3. Formation and organization strategy of socialist union center

\begin{tabular}{lll}
\hline & $\begin{array}{l}\text { Penetration } \\
\text { (centralized) }\end{array}$ & $\begin{array}{l}\text { Diffusion } \\
\text { (fragmented) }\end{array}$ \\
\hline External & German ADGB & Norwegian ALF \\
legitimation & Swedish LO & Austrian BFG \\
(party-led) & Belgian CGSB & Dutch NVV \\
Internal & British TUC & French CGT \\
legitimation & Swiss SGB & Danish DSF \\
(union-led) & Italian CGL & Irish ITUC \\
\hline
\end{tabular}

a union center was set up (LO, 1898) and-collective party affiliation remained in practice for most local unions until recently. In Belgium, the party coordinated union activities via a union committee (CS, 1898) within its structure, and only in 1937 the union center became independent of the party (CGTB). In all three countries the authoritarian or conservative regimes aimed at excluding Socialists from political participation while incorporating the working class, thereby fostering the political mobilization of the labor movement for franchise and political reform. ${ }^{63}$

In the second case, the formation sequence was reversed. The union movement became entrenched before a Socialist party could exert a centralizing influence (the labor party type). Thus the organization of economic interests had already advanced by the time Socialist ideas spread, in fact, the rather "moderate" unions set up a union-led political party. This was the formation pattern in countries with strong apolitical, localist and sectionalist craft unionism that had obtained collective agreements for some trades (Britain, Switzerland and Denmark). In Britain, the Trades Union Congress (TUC) met regularly (since 1869) long before the Socialist splinter parties of the 1890s, but remained a weak forum of autonomous unions and local councils (at least until the reforms of 1895 and 1918). The Labour Party was formed on the initiative of some TUC unions, Socialist parties, and cooperatives. First a parliamentary pressure group (LRC, 1900), it later became a party organization (Labour Party, 1906), though with mere collective membership, and only after 1918 a party with individual mass membership, albeit the "union bloc" vote remained dominant. In Switzerland, local craft unions founded a union center (SGB, 1880) that remained marginal until its

${ }^{63}$ In Belgium several general strikes for suffrage reform were called out after the "black year" of 1886, albeit with limited immediate success, universal but unequal (plural voting) manhood suffrage was granted in 1898. In Sweden, the general strike of 1902 failed as well and manhood suffrage was extended only in 1909. The German debate over the general strike was about the submission of labor unions to the political, electoral strategy of the Social-Democratic party. Parallel to the manhood suffrage for the relative powerless Imperial diet since 1871, a three-class election system was applied in Prussia until 1918. 
reform of 1905 when it allied with the Socialist party. In Denmark, a union center was formed first in Copenhagen (DSF, 1886), later nationally (1898), but remained long dominated by fragmented craft unions. In these countries, the pre-war votes for the Socialists did not match the size of the unionized workforce despite - or paradoxically because of - a relatively large enfranchised population. The liberal constitutions of Britain and Switzerland provided a gradual inclusion of skilled workers, reinforcing craft sectionalism and in Britain Lib-Lab alliances.

In the third case, the party preceded the unions, but was not sufficiently centralized to push the union movement towards centralization (the late-comer type). This pattern represents incomplete forms of party-led union centralization due to organization problems under late industrialization and incomplete national integration (Norway, Austria, the Netherlands). In Norway, the party coordinated local union activities before a union center was formed (AFL, 1899) that only slowly became a national organization although local co-optation and collective partyaffiliation remained. In Austria, a union center was formed when the party was still in its infancy (1893), but centralization succeeded, as in Norway, only in the inter-war period. The Dutch union center (NVV, 1905) was set up by the reformist Socialist party as a rival to the syndicalist unions after a disastrous railway strike in 1903. Only shortly before World War I did party and unions start to centralize and integrate local structures, not without facing localist, syndicalist (Norway and Netherlands) or nationalist-ethical (Austria) counter-movements.

In the fourth case, both party and unions developed independently, overlapping in activities and competing over working-class alliances (the peripheral type). These countries showed large regional disparities (France, Italy and Ireland) with a belated, regionally unbalanced industrialization and entrenched agrarian regimes. They failed in a double sense: the union movement was not strong enough (or willing) to build a political organization of its own; nor was there a political party that molded union centralization. The French union center (CGT, 1895) maintained a double structure of territorial and functional representation (Bourse vs. national unions), thus both politicized locals and moderate unions had an equal voice. CGT enshrined its syndicalist strategy (Charte d'Amiens), disapproving party-union relations in 1906, just when a united Socialist party finally emerged (SFIO, 1905). In Italy, national unions and the Chambers of Labor coexisted, preceding the union center (CGL, 1906). Moreover, CGL's close links with the Socialists led to internal political feuds and a syndicalist split-away (USI, 1912). In Ireland, late industrialization, the national problem and incomplete disengagement from the British TUC, were major obstacles to party-union links and radical syndicalism soared in the 1910 s. They all fell into the syndicalist fallacy: a union movement that hails direct action to be autonomous 
but is, except for few instances, unable to mobilize on a large scale and achieve its political aims.

\section{THE CHURCH-STATE CLEAVAGE}

In some countries, religious conflicts cut across the labor-capital cleavage, thereby splitting worker alignments. For social cohesion of political parties, it has been claimed that "religious divisions, not class, are the main social basis of parties in the Western world". ${ }^{64}$ In Western Europe, we find three clusters of religious composition crystallized after the Reformation: national states with Catholic monopoly, Protestant monopoly (or pluralism), and a "mixed pattern" that is both Catholic and Protestant. ${ }^{65}$ Moreover, the religious factor, the impact of church-state relations, religious heterogeneity, and the degree of toleration of dissident religious groups are spread unevenly across Western Europe. ${ }^{66}$ In Catholic countries the church remained an independent (transnational) structure of authority that often conflicted with the secular national state. In Protestant Europe the established church was part of the nation-building process, though in Scandinavia dissidents mobilized in short-lived religious revivalist movements, while in Britain -new denominations emerged and were tolerated. In "religiously mixed" countries, the coexistence of denominations remained a problem for national integration - requiring consociational accommodation in society and polity, hence developing particular relations between state and organized interests. ${ }^{67}$

What is important for the organization of labor interests is not the religious composition alone but the different reactions to modernization that broke down religious bonds in working-class communities, often leaving Socialism as the sole ersatz religion. The church, in particular the Catholic church, remained a major adversary to the centralizing national state and the liberal-materialist market economy. Since the French Revolution the national state has attempted to limit the power of the Catholic church, to cut its transnational ties with the Vatican, to intervene in internal church hierarchy, to curb its income and privileges, to regulate civil marriage, and to take over its welfare activities. However, the dominant conflict was over secular or spiritual influence on

(4) Richard Rose and Derek Urwin, "Social Cohesion, Political Parties and Strains in Regimes", Comparative Political Studies, 2 (1969), p. 12.

65 David Martin, A General Theory of Secularization (Oxford, 1978).

66 John T.S. Madeley, "Politics and Religion in Western Europe", in G. Moyser (ed.), Politics and Religion in the Modern World (London, 1991), pp. 28-66.

${ }^{67}$ For consociational accommodation see Lehmbruch, Proporzdemokratie; Lijphart, Politics of Accommodation; and Lorwin, "Segmented Pluralism"; for the "religious base" of variations in organized interests see Crouch, Industrial Relations, ch. 9. 
primary education. ${ }^{68}$ The schoolstrijd (school war) mobilized religious communities against the secular national state and led to the formation of parties of religious defense, out of which Christian-Social parties grew. ${ }^{69}$ The historic compromises between liberal-secular and religious forces became the founding stone of verzuiling (pillarization) that had its impact on both the party system and the union movement. ${ }^{70}$

The formation of Christian unions remained a tardy and paradoxical process compared to the Socialist labor movement (see Table 4). ${ }^{71}$ Ideal-typically, the early religious organization of workers was initiated by benevolent priests or bourgeois honoraries to safeguard the spiritual community and provide social welfare to the needy. These clergy-led organizations remained mainly of local scope, non-political and less directed to economic problems. After the encyclica Rerum Novarum (1891), the Catholic church gradually recognized the economic base to social misery and eventually allowed functional interest representation. However, the church long preferred Fachvereine (craft associations) linked to clergy-led cultural associations over separate lay-controlled, strike-prone unions. ${ }^{2}$

The German local and national unions that emerged since the 1890s formed the first Christian union center in Europe (GCGD, 1899), which was - against the will of the Catholic church - ecumenical, albeit only few Protestants joined. Similar attempts at interdenominationalism were curtailed by the Dutch Bishops' ban (1906) leading to a Protestant (CNV, 1909) and a Christian union center (RK-Vakbureau, 1909, later: NKV) that lasted seventy years. In Austria, Belgium, the Netherlands and Switzerland, the pro-union Christian-Social movement developed in opposition to the church-led conservative leaders of the Christian movement, especially Catholic Action. In these countries, the scattered national and local unions only became slowly federated after the turn of the century. Where the church had been most intransigent toward

${ }^{68}$ Lipset and Rokkan, "Cleavage Structures", p. 15; cf. Abram de Swaan, In the Care of the State: Health Care, Education and Welfare in Europe and the USA in the Modern Era (Cambridge, 1988), pp. 83-87.

${ }^{69}$ Lipset and Rokkan, "Cleavage Structures", p. 15.

to Cf. Hellemans, Strijd om de moderniteit.

" On Christian union movements see Patrick de Laubier, Historie et sociologie du syndicalisme: XIXe-XXe siecles (Paris, 1985), ch. 2; Michel Launay, Le Syndicalisme en Europe (Paris, 1990); Patrick Pasture, Christian Trade Unionism in Europe since 1968 (Aldershot, 1994); Hans Righart, De katholieke zuil en Europa: het onstaan van verzuiling onder katholieken in Oostennijk, Zwitserland, België, Nederland (Meppel, 1986); S.H. Scholl (ed.), 150 jaar katholieke Arbeidersbeweging in West-Europa (Brussels, 1961); and Visser, Inclusive Unionism; on Christian Democratic parties see Michael P. Fogarty, Christian Democracy in Western Europe 1820-1953. (London, 1957); and R.E.M. Irving. The Christian Democratic Parties of Western Europe (London, 1979).

"Not everywhere did the "Gewerkschaftsfrage" (union question) provoke church intervention as in Germany (Berlin vs. Cologne movement) and the Netherlands (Limbourg vs. Leiden school) but the potential conflict existed in all Christian labour movements. 


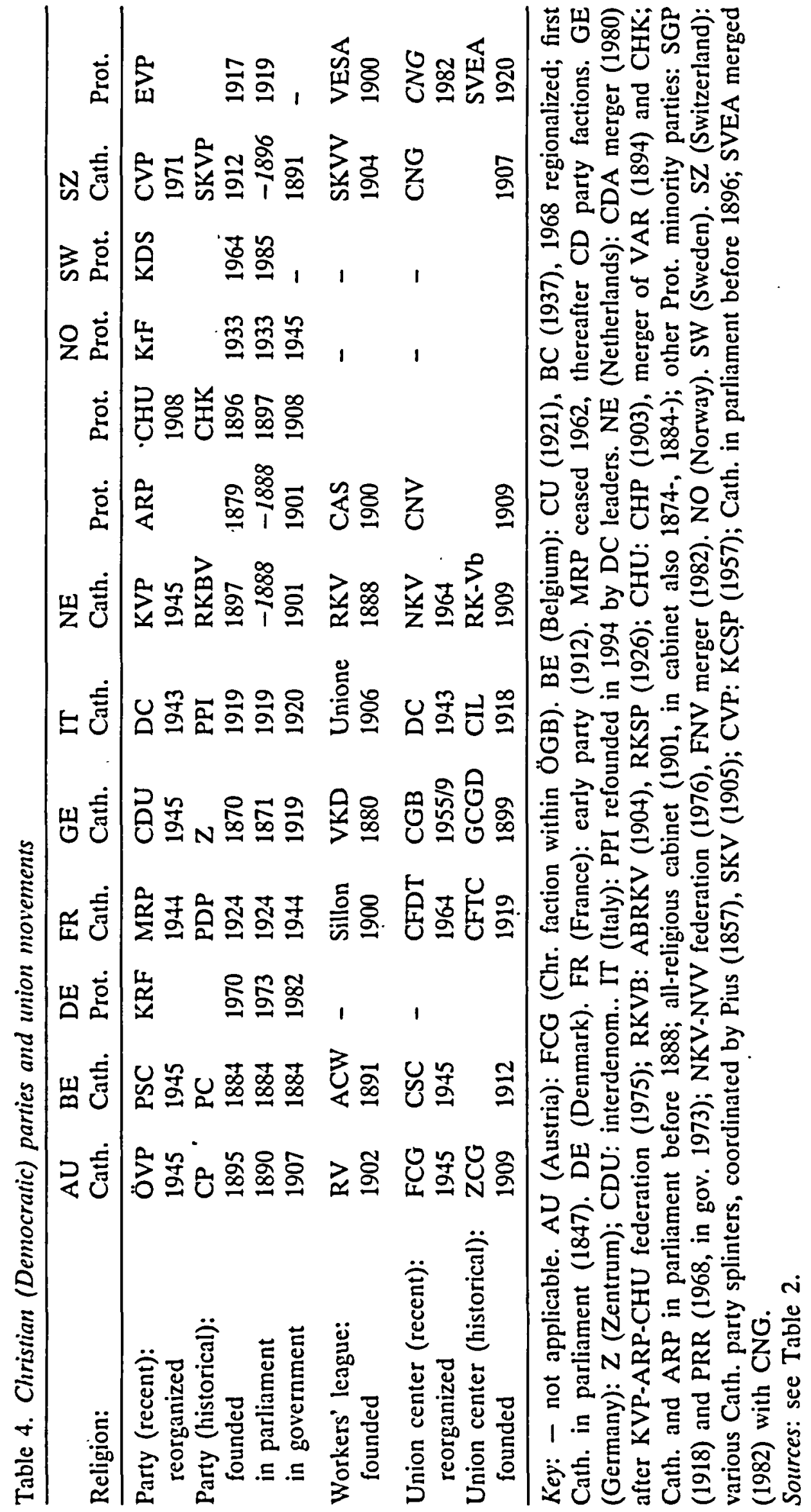


Christian-Democracy and the union movement, as in France and Italy, a Christian trade union center which could coordinate the scattered local and national unions was achieved only after World War I. ${ }^{73}$ The Dutch Calvinist union movement, the only major Protestant union center in Europe, dates back to a split from the Liberals over schoolstrijd, yet it remained a paternalistic organization (Patrimonium) until after the turn of the century. ${ }^{74}$ In Northern Protestant Europe, in Scandinavia and the British Isles, church-going workers remained in the same union movement as Socialist workers. In Britain some dissident denominations participated actively within the labor movements, while the Scandinavian Socialist movement remained, as on the continent, largely atheist.

There is a parallel in party and union development. In countries where no Christian Democratic party emerged, there was also no schism of the labor movement along religious lines. Christian Democratic parties did not emerge in the British Isles, while only belated and small Christian parties were formed in Protestant Scandinavia. In contrast, in the religiously mixed states and the Catholic countries, Christian Democratic parties emerged, albeit of different scopes and strengths. In the group of countries with Catholic or mixed religious composition there occurred a split in the labor movement, too. Yet the claim "that it was not pillarization that created the political parties, but the political parties which gave rise to the process of pillarization"7s seems only partly confirmed. Pillarization was a counter-mobilization to the secularizing tendencies of modernization and partly a reaction to the threat by Socialism. ${ }^{76}$ In contrast to the Socialist camp, it is not so important that the party founded the unions, but that the Christian Democratic party became the crystallizing point for mobilization. The new Christian labor unions sought party support and pressed within the party for organized labor's influence. Christian union movements were being built in response to Socialist labor movements (about four to ten years afterwards), though with a much longer time lag in countries where the church was intransigent (France, Italy). Neither in membership nor in organizational structure did the Christian unions compare with the older, better organized, more encompassing Socialist union movements. The Belgian and

73 The Italian CIL (1918) and French CFTC (1919) were hardly representative, the first being concentrated mainly in Lombardia, Veneto and agricultural areas, whilst the latter was founded by a Paris-based clerical union and labor unions from Alsace.

74 In Switzerland, a Protestant union center (SVEA) emerged in 1920 but remained small and became part of the Catholic CNG in 1982. There also exists a small and peripheral Christian union in Denmark.

75 Rudolf Steiniger, "Pillarization (verzuiling) and Political Parties", Sociologische Gids, 24 (1977), p. 252.

${ }^{76}$ On the modernization thesis see J.E. Ellemers, "Pillarization as a Process of Modernization", Acta Politica, 19 (1984), pp. 129-144; on the socialist threat thesis see Siep Stuurman, Verzuiling, kapitalisme en patriarchaat: Aspecten van de ontwickeling van de moderne staat in Nederland (Nijmegen, 1983). 
the two Dutch movements, the best organized Christian union movements in Europe, attained more than a quarter of the Socialist unions' size in the pre-war period, while all the others fell much shorter. ${ }^{7}$

\section{THE REVOLUTION-REFORM CLEAVAGE}

Communist parties emerged universally in Western Europe in a time of increased political and social mobilization, if not radicalization, after World War I. Inspired by the Bolshevik Revolution and shaken by the post-war economic crisis, many workers joined revolutionary action and works' councils. For them, the reformist road to Socialism had become obsolete and Socialist parties were discredited by their war cooperation. Although all Communist parties affiliated to the Comintern between 1918 and 1923, the break with the reformist Socialism took different organizational forms, despite "proletarian internationalism" and the domination from Moscow that attempted to enshrine its model of "democratic centralism". ${ }^{78}$ Nevertheless, compared to the two other cleavages, the Communist party formation was more universal and relatively synchronous (see Table 5). However, cross-national differences existed in the strength of Communist parties and therefore the available union organizing strategies. Although Communist parties emerged everywhere, Communism implanted itself with varying success in the working-class and union movement. The party was able to impose its leadership on the union movement in only few cases.

A political split in the labor movement did not lead to union schism in all countries. ${ }^{79}$ Three union organizing strategies of Communist parties, partly contingent on the strength of Communist parties at the time, can be distinguished. First, the capturing of a union center, where the Communist party finds a near majority for a radical turn, though risking a split in the labor movement. Second, the organization of a more or less formal union opposition within the existing dominant union movement where the party finds enough supporters and weak resistance, thereby increasing internal factionism. Third, the Communist infiltration strategy entailing the organization of Communist-led rank and file action

$\pi$ Ebbinghaus, Labour Unity in Union Diversity, ch. 4.

${ }^{78}$ Although with the establishment of the Communist International in Moscow (Comintern, 1920) and the Red International of Labor Union (RILU, 1921) the Soviet Communist movement enshrined its leadership role in Lenin's 21 conditions for affiliation. On Communist parties see Michael Waller and Meindert Fennema (eds), Communist Parties in Western Europe: Decline or Adaptation? (Cambridge, 1988); and on "democratic centralism" see especially the contribution by Michael Waller, "Democratic Centralism, the Costs of Discipline", pp. 7-25.

7n On Communist and syndicalist union movements see national accounts in Marcel van der Linden and Wayne Thorpe (eds), Revolutionary Syndicalism: An International Perspective (Aldershot, 1990); and Michael Waller (ed.), Comrades and Brothers: Communism and Trade Unions in Europe (London, 1990). 


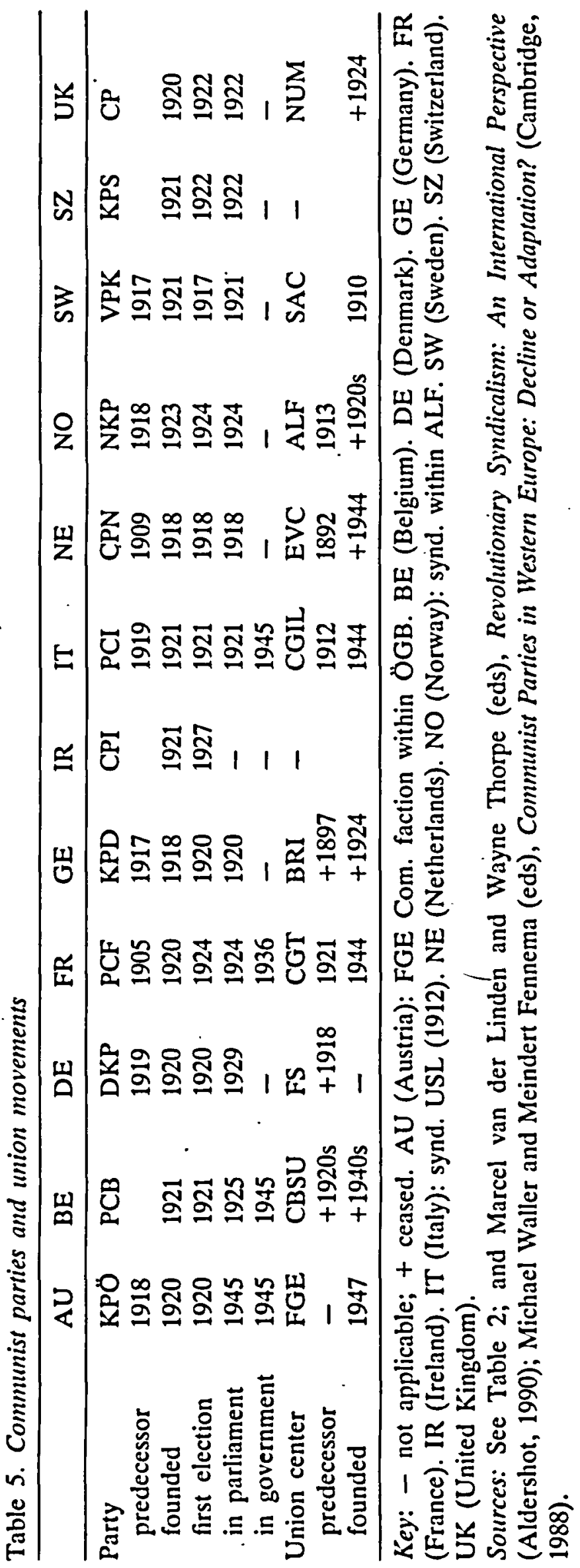


(Communist cells, ad hoc direct action). The first strategy can only be successful where the Communist party has enduring mass support, as in France and Italy. French and Italian Communists, in a majority (or strong) position at the Socialist party congress in 1920, provoked a schism of party and unions, though in Italy, Fascist suppression prevented the latter from happening. In both countries Communist union tendencies reemerged even stronger with the liberation. Yet it provoked nonCommunist unionists to leave the captured union center (French CGT and Italian CGIL) within the first post-war years and found rival organizations (in France: CGT-FO and FEN; in Italy: CISL and UIL in 1947/1948). In countries with existing separate syndicalist union centers, the Netherlands (NAS in 1920s, EVC 1944-1959) and Sweden (SAC), Communists were organized, against Moscow's skepticism, outside the majority labor movement (Dutch NVV, Swedish LO), albeit without much success.

Communism implanted itself particularly where pre-war syndicalist movements had been pervasive. Rokkan has forwarded a historical explanation of Communism in inter-war Europe that postulates a split within the working-class movement under two constellations. ${ }^{80}$ First, a split emerged in Protestant or mixed countries with a recent nationbuilding process, where conflicts over cultural standardization and national identity persisted, as in Norway and the German Reich (also Finland and Iceland). Second, in Catholic countries where the churchstate conflict was deep and persistent, so therefore was the fragmentation of the working class, as in France and Italy (and also Spain). Rokkan's thesis holds for the fragmentation of left-wing parties in France and Germany, and to a lesser degree in Italy and Norway. In these four countries Communism had a large impact on the union movement, yet the split took different forms; from internal and regional radical opposition in Germany, to an oscillation in orientation within the Norwegian labor movement, to a split-up in France. ${ }^{81}$ To account for the post-war development, this explanation should be adapted to a time-dependent explanation. In Catholic countries with a strong church-state conflict, France and Italy, the fragmentation of working-class parties and unions persists. With the reconsolidation of the national states in Norway and post-war West Germany, however, working-class radicalism has become as limited as in the other non-Latin countries.

20 Rokkan, "Nation-Building", pp. 207-208.

81 In Norway, the syndicalist trade union opposition (NFO) captured first the labor party (DNA) in 1918 and thereafter the union center (ALF), affiliating for some years with the Communist International, but in 1923 the Communist party split away. In Germany, Communist trade union opposition was strong within the metalworkers union (DMV) and coexisted with Communist movement in the Ruhr area. 


\section{THE PARTY-UNION FAMILY TREES REVISITED}

To enhance our understanding of political union diversity, let us draw the major ramifications of the organizational choices that led to the specific patterns of political cleavages and party-union relations. The first step will be to discern the major clusters in political unionism, grouping countries with similar patterns of political cleavages together. Such a crude picture provides some clues to hypothesize on the salience of cleavages and the interaction with different forms of party-union relations. In the second step, we will briefly discuss the two processes by which cleavage organizations became institutionalized and persistent. We will finally look at how the current five clusters of political unionism are the outcome of different configurations of national integration in the political and economic sphere. As the evolutionary model suggests, the context under which labor organization emerged molded the relationship between party and unions and the pattern of political unity or schism.

\section{CLUSTERS OF EUROPEAN POLITICAL UNIONISM}

Five ideal-typical clusters of national union systems can be derived from the presented sketch of Western European labor histories. Each cluster represents a particular configuration of cleavage structures; they are: (1) laborist unionism, (2) solidaristic unionism, (3) segmented pluralism, (4) polarized pluralism, and a post-war choice: (5) inclusive "unity" unionism. The first and dominant cleavage that provoked the formation of labor interest organization is the labor-capital cleavage, yet the way in which it affected party and unions varied across Europe. In a number of countries other cleavages intersected with the labor-capital cleavage. There is indeed a hierarchy of political union cleavages: the first four clusters derive from variations in the labor-capital cleavage, two of which were further intersected by the church-state cleavage and the last of which was also divided by the reform-revolution cleavage. The fifth choice remained a post-war compromise to avoid the disunity of the past (see Table 6).

Table 6. Clusters of political unionism

\begin{tabular}{llll}
\hline Political unionism & Main cleavage & Party-union & Country cases \\
\hline Laborist unionism & labor-capital & party $\leftarrow$ union & UK, IR, (DE) \\
Solidaristic unionism & labor-capital & party $\rightarrow$ union & SW, NO, (DE) \\
Segmented pluralism & church-state & party $\leftarrow$ union & NE, BE, SZ \\
Polarized pluralism & revolution-reform & party $\rightarrow-$ union & FR, IT \\
"Unity" unionism & (encompassed) & party $~$ union & AU, GE \\
\hline
\end{tabular}

Key: Party-union influence: $\rightarrow$ unidirectional, $\longleftrightarrow$ mutual, $\rightarrow-$ independent, $\longrightarrow$ deemphasized (see text). 
First, laborist unionism derives from an early and gradual political and corporate integration of sections of the working class. In Britain (and Ireland), gradual suffrage reforms and early collective bargaining by craft unions led to the political and corporate integration of a "labor aristocracy" that voted for Liberal candidates and was proud of craft traditions. Liberal craft unions emerged and preceded the mass workingclass party, most notably in the United Kingdom and Ireland, but also in the early Danish and Swiss union development. The labor party was formed on the initiative of the labor unions, initially as a pressure group for favorable union legislation and political alliance with progressive Liberalism. Only gradually, with the rise of general and industrial unions (that also mobilized the unskilled worker) did the union movement gain a more radical Socialist ideology over "Lib-Lab" orientations. The British and Irish labor parties remained under the influence of the (collectively) allied unions until recently when pressures toward more party independence from union.tutelage have intensified. The labor unions remained less centralized and more fragmented into autonomous sectionalist unions.

Second, solidaristic unionism emerged in countries in which the political integration of the working class was retarded. Socialist political parties were forced to concentrate resources and mobilize for suffrage reform, while the incipient union movement submitted to the primacy of political unionism..$^{82}$ The party assumed leadership and initiated further centralization and coordination of the union movement. Socialist class ideology further reinforced the building of centralized industrial unions, while the counter-mobilization of employers bolstered the need for open cartel and solidaristic strategies. ${ }^{83}$ However, in a number of countries cross-cutting class cleavages intervened leading to a fragmentation of the working class and a limitation of the alliances and electoral successes of the Socialists.

Third, segmented pluralism ${ }^{84}$ led to fragmented labor movements in countries in which the church-state cleavage cross-cut the labor-capital cleavage, that is in Catholic and mixed religious countries. Two competing networks of organizations and segmented social milieus were built under the leadership of the party in the Socialist labor movement, and under the initiative of church circles in the Christian worker movement. ${ }^{85}$ Both "camps" maintained their position through social closure, thereby reinforcing structural inertia. While in Austria and Germany, the interwar Lager (camps) were unable to stabilize the centrifugal political system through elite accommodation, the consociational countries

Lipset, "Reform or Radicalism"; and Marks, Unions in Politics, ch. 1.

83 Fulcher, "Industrial Relations Diversity"; and Labour Movements, Employers, and the State.

sa Lorwin, "Segmented Pluralism".

ss Cf. Hellemans, Strijd om de Moderniteit; Righart, De katholieke zuil; and Stuurman, Verzuiling. 
(Belgium, the Netherlands and Switzerland) preserved and institutionalized a complex system of pillarized accommodation. ${ }^{86}$ Party-union relations are more complex and interdependent in the case of Christian labor movements. The Christian Democratic party is a cross-class alliance that has to encompass and accommodate its internal labor-capital cleavage. Moreover, union pluralism rests on the successful societal pillarization and political accommodation, thus no incumbent party can substantially alter the power balance between the pillars.

Fourth, polarized pluralism ${ }^{87}$. was the result of the revolution-reform cleavage in response to the incomplete institutionalization of the two preceding cleavages. The labor schism occurred where national or cultural integration was lacking or was belated, particularly in France and Italy, but also in inter-war Germany and Norway. ${ }^{88}$ In the two Catholic countries, the church-state split led not only to a fragmentation of organized labor but the left was also divided about a more or less revolutionary "road to Socialism". Employer intransigence and partial exclusion from political integration reduced the possibility of achieving improvements by economic means. In countries where the party-union linkage was incomplete, political fractionalization was common and syndicalism claimed union independence, unionism thus became a political affair.

Fifth, "unity" unionism was the deliberate post-war attempt to encompass political and social cleavages in an all encompassing unitary union movement. After organized labor's defeat in the face of Fascism, German and Austrian union leaders - helped by allied pressures - sought to rebuild a unified union movement (Einheitsgewerkschaft) that would de-emphasize or integrate preexisting political alignments. Also elsewhere, in countries with segmented and polarized pluralism, unionists called for a unity movement during resistance and after liberation. Yet these "unity" pacts broke down during the 1940 s as the political party currents within the union movement again provoked union schism. Only in the 1970s did a rapprochement regain in currency, particularly in the Netherlands (NVV-NKV federation and later FNV merger) and Italy (CGIL-CISL-UIL federation), albeit falling short of the Austrian and German inclusive unionism.

\section{SYSTEM AND SOCIAL INTEGRATION}

The five clusters of political unionism are the outcome of particular historical configurations in the process of labor's integration into polity

${ }^{86}$ Lijphart, Politics of Accommodation.

87 Cf. Giovanni Sartori, Political Parties and Party Systems: A Framework for Analysis (Cambridge, 1976).

${ }^{88}$ Rokkan, "Nation-Building". 
and society. The labor-capital cleavage was the dominant but not sole cleavage along which organized labor mobilized worker interests. Initially, cleavage organizations were formed in a process of social closure and counter-organization through the mobilization of group interests against a contender. ${ }^{89}$ Thus the crystallization of social and political cleavages helped in the early formation and consolidation period, and strengthened collective identity and "class" (or ideological group) solidarity.

However, once "dissident" party and unions passed the thresholds of incorporation and recognition, once they become integrated into polity and economy, cleavage organizations became institutionalized and consolidated. Through the process of system integration, organized labor that formed due to conflicts in the labor market became integrated into the political and industrial relations systems. One can expect these cleavage organizations to become increasingly drawn into political exchange and accommodation. In highly pillarized systems, there exists an entangled network of intra-cleavage and cross-cleavage organizational linkages. As a consequence of system integration, elite interactions and political exchange became common between former "friends and foes", often to the bewilderment of their followers.

The more party and unions became societally integrated and political exchange proliferated, the more these organizations were forced to become hierarchical organizations that sell their "elite deals" to their constituencies. According to Michels' "iron law of oligarchy", ${ }^{90}$ there is an in-built danger that cleavage organizations become detached from their social base. Moreover, through institutional arrangements they tend to monopolize representation against expression of "new comers" or dissident groups of underrepresented interests. With hindsight, we know that neither pillarized consociationalism, nor social-democratic corporatism remained a stable and exclusive system of interest intermediation. ${ }^{91}$ Yet despite the claims for their "end", the institutionalized cleavages account for major differences in long-term state-society relations, that is, the way in which the "political space" is shared.92

${ }^{89}$ Tilly, From Mobilization to Revolution.

${ }^{\circ}$ Robert Michels, Zur Soziologie des Parteiwesens in der modernen Demokratie: Untersuchungen über die oligarchischen Tendenzen des Gruppenlebens (Stuttgart, 1989; 1st pub. 1911).

${ }^{92}$ For instructive country studies on political exchange and a comparison between neocorporatist and consociational theory see Ilja Scholten (ed.), Political Stability and NeoCorporatism. Corporatist Integration and Societal Cleavages in Western Europe (London, 1987); for the "end of corporatism" thesis see Scott Lash and John Urry, The End of Organized Capitalism (Cambridge, 1987).

92 Colin Crouch, "Sharing Public Space: States and Organized Interests in Western Europe", in J.A. Hall (ed.), States in History (Oxford, 1986), pp. 177-210; and Crouch, Industrial Relations, ch. 9. 
Not only organized labor but also their constituency became integrated into society: class and religion lost much of their primacy as a determinant of one's life chances, social behavior and group identity. Thus parallel to system integration, ironically as a result of the very success of cleavage organization, social integration gradually undercut the social base of these cleavages. Processes, like party dealignment, secularization and deradicalization have often been noted in the debate on the decline in cleavage salience. ${ }^{93}$ Although these processes seem to be secular, labor movements differ between countries as to how much they are affected from a loss of party and union alignments through ongoing social change and social integration. In systems with high pillarization and strong opposing cleavages, labor movements were able to maintain allegiance to a higher degree and for longer than in other countries. ${ }^{44}$

The two concepts of system integration and social integration help to map the different degrees of labor's integration in a comparative view (see Figure 2). Early integration in polity and economy led to the emergence of bipolar party systems and laborist unionism (United Kingdom, Ireland), a system that is largely dominated by the labor-capital cleavage. In the case of the relatively homogeneous Scandinavian countries, at least until the accession to power of the Social-Democratic parties in the 1930s, the labor movement remained united against the bourgeois bloc and promoted a solidaristic "class" ideology (Sweden, Norway), though Denmark takes an "in between" status, given its early corporate integration (more like Britain). In countries with social pre-industrial segmentation, the two regimes depended largely on the traditions and timing of elite accommodation. In the case of segmented pluralism (Belgium, the Netherlands, Switzerland), system integration of the cleavage organizations preceded World War II. Under polarized pluralism, strong system opposition, employers intransigence and state intervention remained dominant (France and Italy). In the case of Austria and Germany, the post-war "unity" labor movement had struck an important change towards system integration and encompassing social segmentation. This was a historical post-war response to the disastrous splits of organized labor into polarized Lager leading up to the Fascist authoritarian seizure of power.

${ }^{93}$ See the recent comparative study by Mark N. Franklin et al., Electoral Change: Responses to Evolving Social and Attitudinal Structures in Western Countries (Cambridge, 1992).

90 In recent research on class dealignment in voting behavior, a decline in "cleavage politics" is found to have started in Britain and France before the 1960s, in Denmark and Belgium in the 1960s, somewhat more gradually in the Netherlands and Sweden, and even later in Norway and Italy; see Franklin et al., Electoral Change, p. 394. The continuation of cleavage salience seems to increase from the lack of pillarized cleavage organizations (France, Britain) to political industrial unionism (Denmark, Sweden, Norway), and to still prevailing pillarization (Belgium, Netherlands, Italy). 


\begin{tabular}{|c|c|c|c|}
\hline & SYSTEM INTEGRATION & - ideological distance + & SYSTEM OPPOSITION \\
\hline $\begin{array}{r}\text { SOCIAL } \\
\text { INTEGRATION }\end{array}$ & $\begin{array}{l}\text { Laborist } \\
\text { (sectional) unionism } \\
\text { UK, Ireland }\end{array}$ & (Denmark) & $\begin{array}{r}\text { Solidaristic } \\
\text { (class) unionism } \\
\text { Sweden, Norway }\end{array}$ \\
\hline $\begin{array}{r}- \\
\text { social } \\
\text { distance } \\
+\end{array}$ & & $\begin{array}{l}\text { "Unity" unionism } \\
\text { Austria, Germany }\end{array}$ & \\
\hline $\begin{array}{r}\text { Social } \\
\text { Segmentation }\end{array}$ & $\begin{array}{l}\text { Segmented } \\
\text { pluralism. } \\
\text { Belgium, Netherlands } \\
\text { Switzerland }\end{array}$ & $\begin{array}{c}\text { (Austrian Empire) } \\
\text { (German Reich) }\end{array}$ & $\begin{array}{r}\text { Polarized } \\
\text { pluralism } \\
\text { France, Italy }\end{array}$ \\
\hline
\end{tabular}

Figure 2. Typology of labor's social and system integration

From this historical scheme of political union clusters, an intricate problem of achieving labor unity in Europe can be visualized for the future. To establish a truly encompassing European union movement more than a cross-national "convergence" around an "average way" of organizing labor interests is required. At least four different institutional adaptations are necessary for all movements to "meet" in the encompassing "unity" center (as plotted in Figure 2), and each cluster has to move in a different way. More theoretically formulated: each union system is historically embedded into a particular social structure (segmentation) and into an institutionalized web of interorganizational relations (pillarization). In order to achieve "inclusive unionism" in Europe an encompassing organization has to be formed on the basis and with the support of existing ones. The boundary of labor unity and labor's alliances will have to be redrawn after a century of their encroachment with consequences in both political system and industrial relations. Indeed, this is a formidable challenge to European organized labor!

\section{CONCLUSIONS}

In this paper I have argued that unions and allied political parties as social institutions, their organizational structure, their embeddedness in the social structure and their linkages, have been molded at an earlier time when the corporate and electoral channels were newly open. Major variations in the granting of citizenship rights were shown to shape the formation of party and unions, and their relations. The variations in party and union formation are pronounced and reflect the varying national integration of labor into society and the particular societal conflicts of interest. The paper compared three different political cleavages that led to schisms of organized labor: the Socialist, Christian and 
Communist labor movements. These cleavages are unevenly spread across Europe, splitting the labor movement in some countries and leading to different forms of party-union relations. The labor-capital cleavage was the first and dominant conflict of interest that shaped the formation of working-class party and unions as well as their relations. Depending on the prior transformation of the labor-capital cleavage, the two other conflicts of interests were able to cross-cut working-class allegiance in the electoral and corporate channels of a number of countries.

The cleavage structures and party-union relations remain more enduring than is commonly assumed. We witness today a decline in the salience of political cleavages, an intensification of functional cleavages, and a depolitization of party-union relations. My contention is that labor organizations are slow to adapt due to their social embeddedness and interorganizational linkages. After 1945, only in a few cases was it possible to overcome past union schism in a "unity" unionism. It also took a considerable time until national integration had undermined the bases of pillarized or polarized societies. Strategic decisions may be made, yet the set of alternatives is limited as a result of entrenched decisions and internal vested interests, thus adaptation is path-dependènt.

Social closure and pillarization were once the successful mobilizing and representation strategies of organized labor. Since then desegmentation and depillarization have for decades led to a decline in political cleavage salience. Other cleavages have led to further interest fragmentation of organized labor, such as sectionalist interests in the white-collar or public sector. One may argue that the decrease in political cleavage salience could imply a coming closer of Western European union movements in the light of global competition and European integration. This is not necessarily so: as the limited success of the Christian and Communist transnational movements indicate, cross-border solidarity finds its limits in long-standing national collective identities. Through the opening up of the national electoral and bargaining channels over the last century, the labor movement that started as an "International" became unremittingly drawn into the national polity and society, into the domestic welfare state and Volkswirtschaft (national economy). As a consequence of the citizenship rights granted to labor by national welfare states, working-class parties and unions are veritable national institutions and in the view of radical internationalists even "domesticated" organizations.

The particular configuration of collective rights molded the national integration of labor, the system integration of organized labor into the polity and economy as well as the social integration of labor into the national society. The challenge to today's labor movement is to adapt to a weakening of the regulatory capacity of national states and the lack of worker rights at a global level..$^{95}$ Both the transfer of power to a

${ }^{95}$ Tilly, "Globalization". 
transnational level and the growing dependence on world markets call for "borderless solidarity" at the transnational level, particularly in a more integrated and enlarged European Union, though nationally entrenched union diversity is a considerable obstacle. ${ }^{96}$ On the other hand, recent trends toward regionalization of politics and decentralization in industrial relations provide a further, though sub-national, challenge to national labor movements and centralized industrial relations.

In light of the European challenge and new potential lines of conflict, one should not easily discard the old cleavages. They will stay with us for good or bad - for a long time. Certainly, labor party and allied unions may adapt to some of these changes, and will attempt to redefine the new role of party and unions in a changing society. But if any broad guess can be made, one cannot expect much radical change. Even after the dramatic events in the East since 1989 we still find an inert French Communist party and allied union movement, or the persistence of an ideological split..within the Italian union movement despite the adaptations of the former Communist party (PCI, now PDS). In times of change and crisis, when we do not know what the future will bring, old ideologies often "go a long way", and the already established structures will adapt slowly. Sometimes existent organizations shape the environment and exploit the potential lines of conflict for their own purposes. This may add to a further deterioration in mass alignment and popular legitimation for organized labor. At the end of its century, organized labor stands at a cross-road at which it should reflect upon its past and review its future options.

96 This line of argument is developed in Bernhard Ebbinghaus and Jelle Visser, "Wege und Grenzen 'grenzenloser' Solidarität: Gewerkschaften und Europäische Integration", in Wolfgang Streeck (ed.), Staat und Verbände (Opladen, 1994), pp. 233-255; see also Jelle Visser and Bernhard Ebbinghaus, "Making the Most of Diversity? European Integration and Transnational Organisation of Labour", in Justin Greenwood, Jürgen Grote and Karsten Ronit (eds), Organized Interests and the European Community (London, 1992), pp. 207-237. 